chairman, and after a short discussion it was passed and sent onto the floor of the House, where it was brought up and hurriedly passed in the closing hours of the 1981 session at the end of March.

Governor White lost no time in signing the bill, admitting later that he had not read it before doing so. His decision provoked a storm of protest from scientists in the state, most of whom were unaware of the bill until it had been passed into law. The Arkansas Academy of Sciences at its annual meeting passed a resolution urging that the law be rescinded, as did 300 faculty members of the University of Arkansas at Fayetteville, who complained that the act would hurt the university's reputation.

Governor White, however, has made it clear that he does not intend to take any steps to repeal the law unless it is judged as

\section{Scopes again?}

The present is not the first occasion when Arkansas has been the focus of national attention on the constitutionality of efforts to influence the teaching of evolution in public schools. In 1968 the US Supreme Court struck down a law, introduced into the state in 1928, which made it illegal for any teacher and educational institution supported by state funds to teach "the theory or doctrine that mankind ascended from a lower order of animals".

Following the Scopes trial, no serious attempts seem to have been made to enforce this law. However, the case was passed to the Supreme Court after the statute had been unsuccessfully challenged in the state's Supreme Court by a biology teacher in Little Rock's Central High School, Mrs John O. Epperson.

In declaring the state law unconstitutional, Justice Abe Fortas argued that the 1928 law, enacted in a popular initiative, was a clear effort inspired by the Scopes trial to outlaw all but the "Bible story" of creation. "There can be no doubt that Arkansas has sought to prevent its teachers from discussing the theory of evolution because it is contrary to the belief of some that the Book of Genesis must be the exclusive source of doctrine as the origin of man"' he said.

At the time of the trial, Arkansas and Mississippi were the only states to maintain an anti-evolution law. The fact that the law preventing the teaching of evolution was judged by the Supreme Court to infringe the "establishment of religion" clause in the constitution is expected to be used by the American Civil Liberties Union in its attack on the new law. Scopes himself, then living in Louisiana, hailed the Epperson decision as "what I have been working for all along'. His own conviction was quashed by an appeals court, so he was unable to challenge the constitutionality of the Tennessee law. unconstitutional. And many Little Rock observers feel that he is likely to stick to this position, given the extent to which his surprise victory over incumbent Democrat Governor Bill Clinton last November seems to have been helped by the active involvement of groups such as FLAG and the Moral Majority in encouraging the conservative vote.

As a result, the spotlight is now focused on the ACLU complaint, which both sides see as setting important precedents. Groups which are likely to support ACLU include the National Association of Biology Teachers, which has long campaigned about allowing creationist theories to be placed on the same level as evolution in school biology classes. And the President of the Arkansas Academy of Sciences, Professor John Kenneth Beadles, head of the State University of Arkansas' biology department, is suggesting to fellow academy members that they add their support to the ACLU effort.

The creationists are getting ready to meet the challenge. One of the principal advisers on the drafting of the Arkansas Bill is said to have been Wendell Bird, an attorney who was at one time an editor of the Yale University Law Review, and who now works with the Institute for Creation Research in San Diego, California. The institute, as a tax-exempt organization, takes pains not to be seen to be involved in legislative campaigns; however, Mr Bird's writings are referred to by $\mathrm{Mr}$ Ellwanger and others as powerful support for the argument that the teaching of creationscience can be defended by referring to rights guaranteed by the constitution.

If ACLU wins its case, either at the district court level, during the appeals process, or in the Supreme Court, it will be a major setback not only for the creationist movement - which now claims over 750 scientists among its ranks - but also for the broader poltitical strategy of the conservative right. If it loses, it will be a significant boost to creationists, who are already predicting that bills similar to that passed in Arkansas are likely to be introduced in 40 state assemblies next year.

Pressure is also building up at a federal level. Several Congressman have received a model bill promoting research support for "creation-science", from a group, also headed by $\mathrm{Mr}$ Ellwanger, called the Citizens Against Federal Establishment of Evolutionary Dogma. It seems only a matter of time before some congressman introduces the legislation.

The two sides are as far apart as ever. $\mathrm{Mr}$ Ellwanger argues that "fairness should not be an option; we now have the tools to insist that fairness be mandated by law, in the interests of academic honesty'. The Arkansas Gazette, which has carried out an uncompromising campaign against the bill, warns that it will brand the state as a "bastion of know-nothingness in the teaching of science." The court case is unlikely to stay polite. David Dickson
Sakharov conference Birthday honour

\section{New York}

The two-day conference at Rockefeller University on 1-2 May in honour of Dr Andrei Sakharov was an ironic occasion. The opening day was celebrated in the Soviet Union with the customary package of approved slogans, the forty-first of which reads "Soviet scientists! Improve the effectiveness of research! May the alliance between creative thought and creative labour be much stronger!' Sakharov meanwhile remained in internal exile in Gor'kii.

The conference had bcen called in part to mark Sakharov's birthday on 21 May and consisted of three parts - Sakharov's work in science, for nuclear disarmament and for human rights. Among the scientific papers was one by John Archibald Wheeler (University of Texas) on Sakharov's "sausage-skin" cosmology, another by Harold Furth (Princeton) on Sakharov's contributions to fusion research and a third by Val Fitch (Princeton) on anti-matter asymmetry. Those present nostalgically recalled Sakharov's involvement with the international scientific community in the past twenty years and argued that his present isolation was tantamount to bringing his scientific career to an end.

The conference was at something of a loss to reconcile Sakharov's work on the Soviet thermonuclear bomb in the $1950 \mathrm{~s}$ with his more recent concern for disarmament; the argument that by assisting in the strategic parity between East and West he was helping to satisfy one of the realistic preconditions of disarmament was regarded by some as artificial and by others as unnecessary.

Sakharov's own message to the conference (see page 184) was largely concerned with human rights and, in particular, with the plight of Soviet citizens other than himself. On the question of the relationship between professional scientists in the West and their Soviet colleagues, Antonino Zichichi, president of the European Physical Society, told the conference that more than a thousand scientists had undertaken that until the end of this year, all scientific papers submitted for publication would bear the legend "In honour of the 60th birthday of Andrei Dmitrevich Sakharov'. For the time being, however, the disputed question of a scientific boycott of the Soviet Union such as that organized last year, although aired at the conference, has been allowed to lapse.

Another of the ironies of the timing of this month's conference is that it followed soon after the celebration of the twentyfifth anniversary of the Joint Nuclear Research Institute at Dubna, south of Moscow. In a full-page feature in the daily newspaper Sotsialisticheskaya Industriya, attention was drawn to the search for 